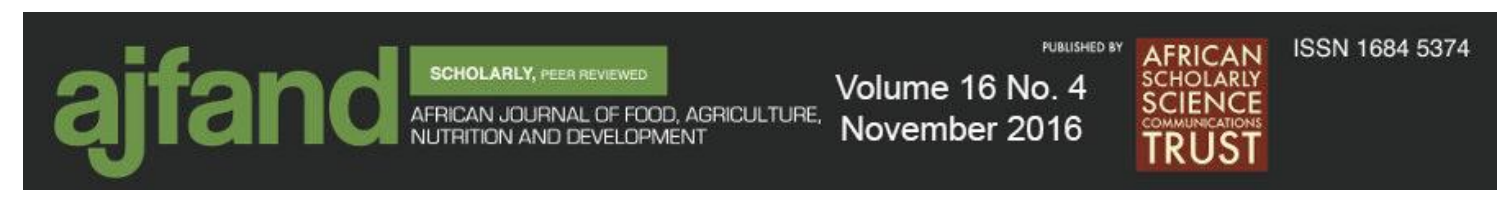

\title{
DOI: 10.18697/ajfand.76.15685
}

\section{EFFECTS OF WEATHER EXTREMES ON CROP YIELDS IN NIGERIA}

\section{Ajetomobi JO ${ }^{1^{*}}$}

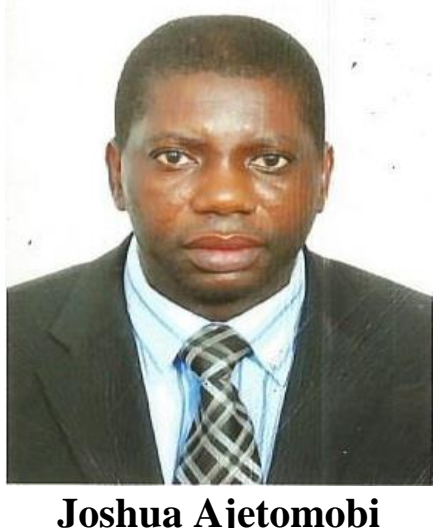

Joshua Ajetomobi

*Corresponding Author email: jsegun2002@yahoo.com

${ }^{1}$ Department of Agricultural Economics, Ladoke Akintola University of Technology, PMB 4000 Ogbomoso Nigeria 


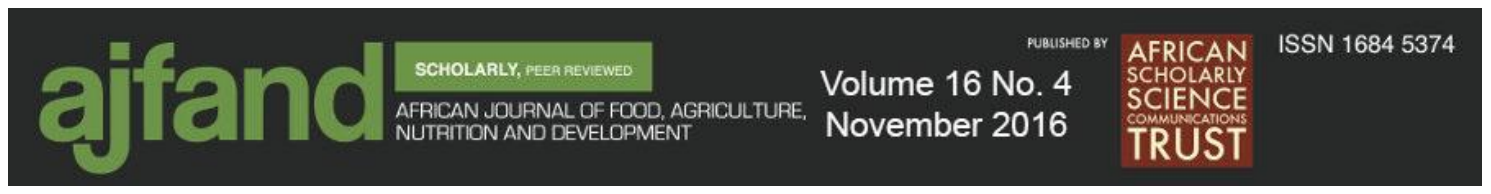

\begin{abstract}
This study seeks to analyze how extreme weather conditions affect crop yield and risk in Nigeria and to assess the potential implications of weather extremes on the nation's crop insurance portfolio. A panel of Nigerian state-level crop yields was paired with a finescale weather data set that included distribution of temperature and precipitation between the minimum and maximum across all days of the growing season for selected crops. Weather data were examined from January 1, 1991 to December 31, 2012. The analysis was started with the traditional approach of estimating climate change impact by a quadratic regression model of weather and Growing Degree Days (GDD) on crop yields using panel data estimation. Later, Harmful Degree Days (HDD) and Vapour Pressure Deficit (VPD) were stepwisely included. Interactions of rainfall, GDD and VPD were also explored. In the production approach, crop yield was specified as a function of weather inputs (temperature and precipitation). The results showed that the time when the lowest and highest yields were obtained differed by crops. The highest $(43.50 \mathrm{~kg} / \mathrm{ha})$ and lowest $(1.085 \mathrm{~kg} / \mathrm{ha})$ yields for cassava were observed in 1999 and 2001, respectively, while both highest and lowest yields for sorghum were recorded in 2012. Daily maximum temperature between 30 and $35{ }^{\circ} \mathrm{C}$ occurred more than a 1000 times over all the days covered in this study (January 1, 1991 to December 31, 2012). The regression results showed that high damage to cassava, cotton and maize was evident by the strong and negative coefficient of Harmful Degree Days (HDD). For sorghum and rice, an exposure to heat range showed a negative influence on the yield. In order to address the negative weather effects and other problems associated with the National Agricultural Insurance Corporation (NAIC) such as little access by farmers, high information asymmetric and transaction costs, crop insurance based on indices from Nigeria Meteorological Agency (NIMET) could be adopted to compensate part of the damage caused to the farm products.
\end{abstract}

Key words: Extreme Weather, Staple Crop, Yield Risk, Agricultural Insurance, Econometrics, Nigeria 


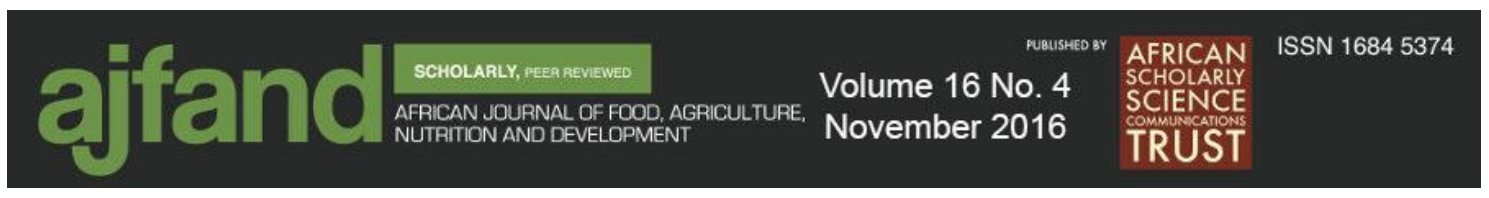

\section{INTRODUCTION}

In both the developing and developed worlds, extreme weather events and climatic anomalies can negatively affect crop yield and disease patterns. For instance, droughts followed by intense rains can increase the potential for flooding, thereby creating conditions that favour fungal infestations of leaves, roots and tuber crops. Sequential extremes, along with altered timing of seasons, may also decouple long-evolved relationships among species essential for controlling pests and pathogens, as well as the populations of plant pollinators [1]. As an example, reduced bees' densities from global climate change have led to local extinction of several plant species. Therefore, an objective assessment of the potential impacts of climate on agriculture should be based not only on the mean values of expected climatic parameters, but also on the probability, frequency and severity of possible extreme events. Hence when user-focused weather and climate information are readily available and used wisely by farmers and agricultural insurance corporations, losses resulting from adverse weather and climatic conditions can be minimized.

In recent decades in Nigeria, major advances in short term and seasonal weather forecasting, as well as in long term climate modeling, are available for early warnings and advisories. These have caused an increasing emphasis on management of the risk to agriculture from extreme weather events and anomalies in climate conditions. Each year, a large amount of government spending in Nigeria is devoted to two major programmes that help farmers manage this risk: subsidized premiums for agricultural risk-reducing insurance policies and frequent ad-hoc disaster payments to reimburse farmers after occurrence of natural disasters. Because of climate change and increased occurrences of extreme weather events, these costs are expected to continue to increase unless proper reforms are put in place. Fundamental to such a reform will be an adequate knowledge of the effects of weather extremes on yields of various crops grown in Nigeria, particularly those covered by its Agricultural Transformation Agenda (ATA).

Traditionally, panel or time series data have been used to assess the influence of weather fluctuations on crop yields. The methods commonly employed include the use of calibrated crop-models, panel regression methods and partial equilibrium frameworks [2, $3,4,5]$. Other modeling techniques include the use of hedonic $[6,7,8]$ and simulation models $[9,10]$. The results from these studies have shown that precipitation and temperature are essential for crop yield improvement. However, above certain thresholds, temperature can be disadvantageous to crop yields. Using area-based agrostatistical surveys and the monthly means of meteorological parameters from 1869 to 2003, it has been shown that extreme weather have caused bad harvests for seven agricultural crop species in three regions of Austria [11].

In order to capture the marginal impact, temperature has been modeled in three ways, namely, monthly average, GDD and HDD [4, 12]. The studies showed that temperatures in the mid-30s $\left({ }^{\circ} \mathrm{C}\right)$ have a different marginal impact than temperatures in the mid-20s $\left({ }^{\circ} \mathrm{C}\right)$. A study showing a comprehensive review of temperature thresholds for a range of crops has been carried out [13]. Such identification of temperature thresholds provides a basis for quantifying the probability of exceeding temperature thresholds, which is an 


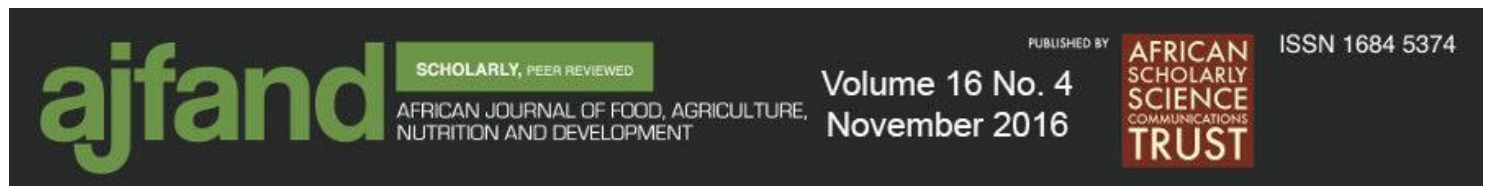

important aspect of climate change risk assessment. The study also affirmed the negative effects of extreme temperatures on yield and yield components.

Presently, little empirical evidence exists on crop yield response to the alterations in climatic conditions in sub-Sahara Africa. Furthermore, a few studies assessed the effects of extreme weather (temperature and/or precipitation) on crop yields in Nigerian states despite regular newspapers' reports of weather-based disasters affecting crop yields. Therefore, this study aimed at investigating how extreme climatic conditions influence the yields of major staple crops in Nigeria.

The specific objectives were to:

(1) Estimate the effect of extreme weather on yields for the following major Nigerian staple crops: cassava, cotton, maize, rice and sorghum.

(2) Draw out potential implications of yield decline due to extreme weather on the nation's crop insurance scheme.

\section{METHODOLOGY}

\section{Econometric Model Specification}

The analysis was started with the traditional approach of estimating climate change impact by a quadratic model of weather and growing degree days on crop yields using panel data estimation. In the production approach, crop yield was specified as a function of weather inputs (temperature and precipitation). In a real world situation, the production function may have other factors such as labor, pesticides, fertilizers, improved crop varieties, other modern technologies and farm owners' adaptation to adverse weather shocks. Lack of available data on such factors, however, did not allow inclusion of the variables in the model. As a result, the model was tested for omitted variable bias. In addition, location and time fixed effects were employed to control for regional differences in soil quality and technological progress or other shocks across a given geography and time. The panel models relied on an assumption of no adaptation so as not to overestimate the impact of a negative shock.

The production function is shown in model 1 below:

Model 1: $\log \left(Y D_{i t}\right)=\beta_{0}+\beta_{1}$ Tave $_{i t}+\beta_{2}$ Rain $_{i t}+\lambda_{1}$ Tave $_{i t}^{2}+\lambda_{2} \operatorname{Rain}_{i t}^{2}+\varepsilon_{i t}$

Where $Y D_{i t}$ is de-trended crop yield in $\mathrm{Kg} /$ hectare of state $\mathrm{i}$ in year $\mathrm{t}$

Tave $_{i t}$ is average daily temperature for state $\mathrm{i}$ at year $\mathrm{t}$

rain $_{i t}$ is cumulative daily rainfall of state $\mathrm{i}$ at year $\mathrm{t}$

If Growing Degree Days (GDD) and Harmful Degree Days (HDD) are used instead of mean temperature, the equation becomes:

Model 2: $\log \left(Y D_{i t}\right)=\beta_{0}+\beta_{2} \operatorname{Rain}_{i t}+\lambda_{2} \operatorname{Rain}_{i t}^{2}+G D D+H D D+\varepsilon_{i t}$ 


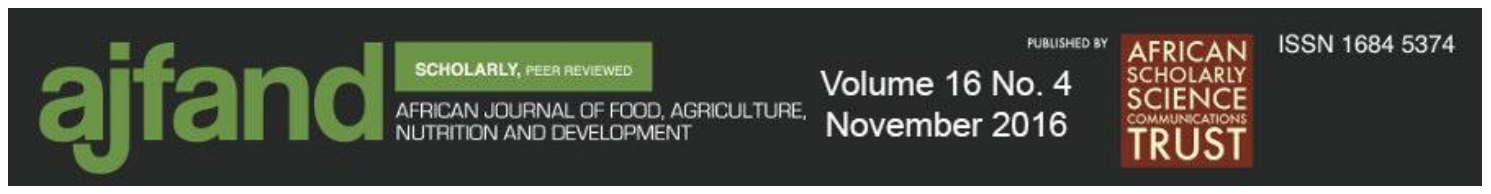

In the third model, Vapor Pressure Density (VPD) is added to the second model

Model 3: $\log \left(Y D_{i t}\right)=\beta_{0}+\beta_{2} \operatorname{Rain}_{i t}+\lambda_{2} \operatorname{Rain}_{i t}^{2}+G D D+H D D+V P D+\varepsilon_{i t}$

In the fourth model, the interaction of rainfall, GDD and VPD were explored. Crop physiologists indicate that these interactions are crucial [13]. In the modeling process, all pair-wise interactions of rainfall and its square with each of GDD, HDD, VPD and VPD were tried. This was followed by selective addition and removal of terms through stepwise regression procedure so as to minimize Bayesian information criteria (BIC).

Model 4:

$\log \left(Y D_{i t}\right)=\beta_{0}+\beta_{2} \operatorname{Rain}_{i t}+\lambda_{2} \operatorname{Rain}_{i t}^{2}+G D D+H D D+V P D+\operatorname{Rain}$ GDD $+\operatorname{Rain}^{2} G D D+\operatorname{RainHDD}^{2}$

$+\operatorname{Rain}^{2} H D D+\operatorname{Rain} V P D+\operatorname{Rain}^{2} V P D+\varepsilon_{i t}$

GDD and HDD are growing degree days $\left(8-32^{\circ} \mathrm{C}\right)$ and harmful growing degree days (temperature greater than $34^{\circ} \mathrm{C}$ ), respectively.

The best models for selected crops are the ones with the lowest root mean square error (RMSE). Another criterion used for the selection is the significance of the variables as well as the models' $t$ and $F$ statistics

\section{Description of the Dataset}

The weather data (temperature and rainfall) in each state were matched up with the yield of each crop over the particular crop growing season.

\section{Crop Yields}

Annual crop yields for five major crops including maize, sorghum, cotton, rice and cassava were obtained from the official records of each state Agricultural Development Programme. These crops were selected because they constitute priority staple food commodities under the nation's Agricultural Transformation Agenda (ATA) action plan. The data are available for all states in the country from 1991 to 2012. The records include information on total production, land area, number of farmers growing each crop and the crop's market price. Each state-average yield is derived as total production divided by total harvested hectarage. Table 1 shows the highest and lowest individual yield observations, by crop, in the dataset. That table shows that the highest yield $(43.50 \mathrm{~kg} / \mathrm{ha})$ for cassava was observed in 1999 while the lowest yield $(1.085 \mathrm{~kg} / \mathrm{ha})$ was observed in 2001. For sorghum, both highest and lowest yields were recorded in 2012. The yield is defined as

$\mathrm{YD}=100 \times(\log ($ Yield $)-\log ($ Trend $))[13]$

Where YD is de-trended yield 


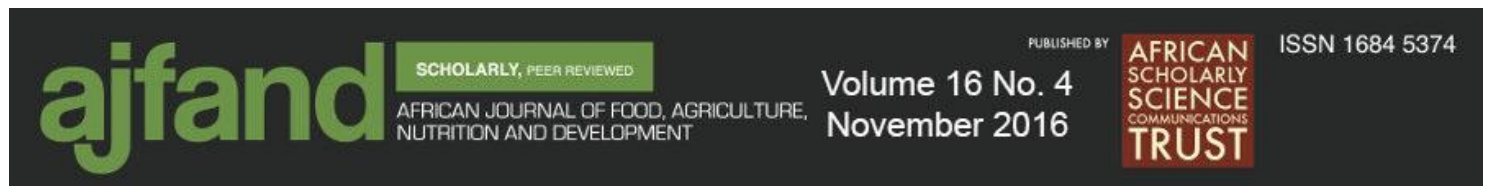

The basis for de-trending includes: (i) yields have trended up with technological advancement, (ii) trend explains a large portion of the overall variance, de-trending therefore will ensure that the $\mathrm{R}^{2}$ only measures the effect of weather variables, and (iii) a log standardization correctly and parsimoniously accounts for relationship between yield and both the mean and variance of the trend variable.

\section{The Growing Season}

The growing seasons for the selected crops are shown in Table 2. The growing seasons depend on whether the crop is grown in the northern or southern part of Nigeria. In addition, maize and rice have two growing seasons in the country. The growing seasons for the selected crops are determined by the major planting days and harvest days reported by United States Department of Agriculture (USDA). The planting and harvesting days vary from Northern to Southern part of Nigeria. They also vary from year to year depending on weather severity. Therefore, the growing season included in the empirical analysis for each crop cuts across the two regions.

\section{Climate Variables}

Weather data (temperature and rainfall) obtained from National Meteorological Agency, are examined from January 1, 1991 to December 31, 2012. The variables are described as follows:

\section{Temperature data}

Three temperature variables, namely, average temperature, growing degree days (GDD) $\left(10-32^{\circ} \mathrm{C}\right)$ and Harmful Degree Days (HDD) $\left(34^{\circ} \mathrm{C}\right.$ and above) were calculated from minimum and maximum daily temperature reported in Nigerian Meteorological Agency (NIMET). Missing values observed in the data were interpolated by taking a simple average of two dates that were adjacent to the missing period [4]. In estimating the effect of extreme temperature on yield, it is essential that the data set contains sufficient instances of crop exposure to heat over $30{ }^{\circ} \mathrm{C}$. Figure 1 shows the distribution of temperature by month for the nation. The frequency count was calculated using the daily maximum temperature value from 1991 to 2012. The highest temperature in the weather dataset was $46^{\circ} \mathrm{C}$ and occurred in March and April. The figure showed that temperature above $30{ }^{\circ} \mathrm{C}$ was common but above $40{ }^{\circ} \mathrm{C}$ was less common. Daily maximums between 30 and $35^{\circ} \mathrm{C}$ occurred more than a 1000 times over all the days covered in this study (January 1, 1991 to December 31, 2012). Hence, this study assumed that sufficient occurrences of temperatures in the higher ranges exist in the dataset for a yield response to such temperatures to be analyzed econometrically. Various ways by which the temperature variables were defined are stated below. 

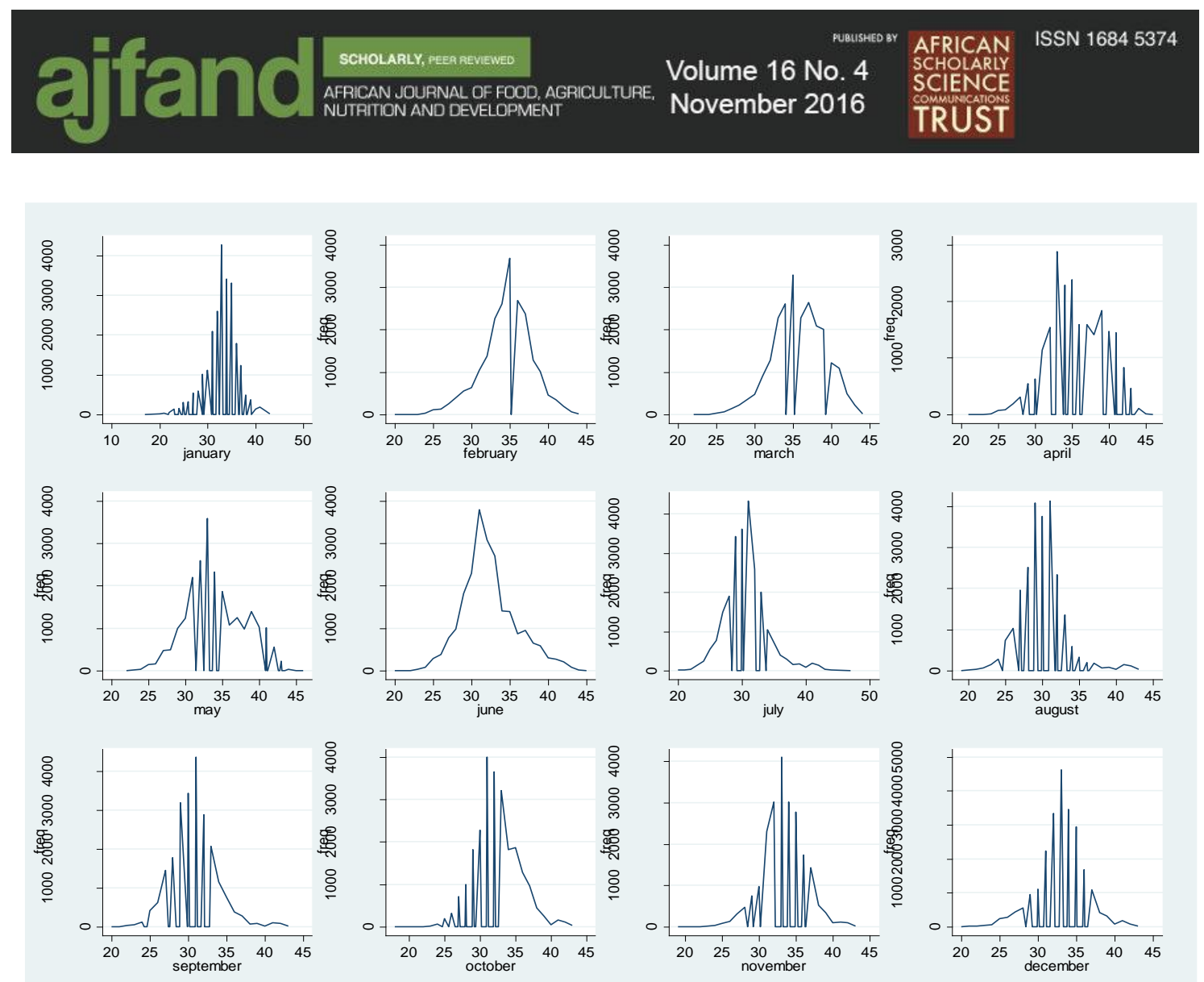

Figure 1: Frequency Distribution of Daily Temperatures $\left({ }^{\circ} \mathrm{C}\right)$ across all Nigerian states by month

\section{Average Temperature}

$\mathrm{TAVG}=(\mathrm{Tmax}+\mathrm{Tmin}) / 2$

Where TAVG is the average temperature

Tmax is daily maximum temperature and

Tmin is daily minimum temperature

The growing season for each crop is spread over several months; hence, the TAVG for each crop was averaged over each crop growing season across its producing states.

\section{Growing Degree Days}

A derivative of extreme temperature commonly used by agronomists to measure the number of heat units crops are exposed to during growing seasons is Growing Degree Days (GDD). The traditional way to calculate GDD is to measure the difference between mean daily temperature and a predetermined threshold [4]. If $T_{h}$ is maximum temperature, $T_{i}$ minimum temperature, $T_{b}$ a given baseline temperature (usually between 8 and $10^{\circ} \mathrm{C}$ ) and $\mathrm{Tm}$ a given upper bound (typically $30-32^{\circ} \mathrm{C}$ ), then, over all days, growing degree days can be calculated as

$$
G D D=\left\{\frac{T_{h+} T_{i}}{2}, T_{m}\right\}-T_{b}
$$


In this study, the baseline was assumed to be $10^{\circ} \mathrm{C}$ while the upper bound of $32^{\circ} \mathrm{C}$ was chosen. An advantage of GDD over mean daily temperature is that the computation considers the fluctuation between daily maximum and minimum temperature. For example, a daily range of 35 and 25 degrees has the same mean temperature ( 30 degrees) as a daily range of 40 and 20 degrees, which is within the optimal temperature range [12]. In defining HDD, the lower bound was assumed to be $32^{\circ} \mathrm{C}$ with no upper bound. In multiple regression analysis, GDD is expected to influence yield positively while coefficient of HDD is expected to be negative. To obtain the GDD and HDD values for the yield model, their daily values are aggregated over each crop growing season [13, $14]$,.

\section{Rainfall data}

Rainfall data were also obtained from NIMET in the form of daily rainfall measured in $\mathrm{mm}$. The data were summed over the entire growing season for each crop. Table 3 indicates the summary statistics. The lowest cumulative rainfall recorded for any growing season was $19.6 \mathrm{~mm}$ while the maximum was $4243.1 \mathrm{~mm}$. The average varied from 469.7 $\mathrm{mm}$ to $1495.1 \mathrm{~mm}$. Substantial differences exist in the observation for different crops perhaps due to seasonal as well as spatial distribution in their growth. For instance, sorghum is predominantly grown in the northern part while cassava thrives better in the south. Seasonally, cassava is grown over all the months in a calendar year unlike sorghum.

\section{Vapor Pressure Deficit}

Another variable of interest incorporated in the regression model is Vapor Pressure Deficit (VPD). It is calculated as the difference between how much water the air can hold when it is saturated and how much water it currently holds [13]. Each day's VPD was calculated using the formula shown in equation 9.

$V P D=0.6107\left(\exp ^{\frac{17.269 T h}{237.3+T h}}-\exp ^{\frac{17.269 T i}{237.3+T i}}\right)$

There are two ways by which VPD affects yield or influences weather patterns that affect yield [13]. First, VPD drives water loss via plant transpiration, thereby increasing water requirements [15]. Second, VPD affects diurnal temperature variation, cloud cover and precipitation. Water requirements and VPD are directly proportional while VPD has inverse relationship with cloud cover. Theoretically, therefore, a positive relationship is expected between VPD and yield when soil moisture is adequate and a decreasing relationship when soils moisture is inadequate [16].

\section{RESULTS}

The descriptive statistics of the regression variables are presented in Table 4 while the regression coefficients, $t$ statistics and adjusted- $\mathrm{R}^{2}$ values for the best fit model for all the crops are shown in Table 5. The results for each crop are discussed below. 


\section{Cassava}

Contrary to theoretical expectation, the results for cassava indicate a negative relationship between the yield of cassava and growing degree days while the quadratic relationship is positive. A rise in growing degree days by $1{ }^{\circ} \mathrm{C}$ will cause a decline in cassava yield by about $0.05 \mathrm{~kg} /$ hectare. The marginal relationship of cassava yield with harmful degree days (HDD) is strongly negative. The result clearly implies that temperatures from $34^{\circ} \mathrm{C}$ and above are harmful for the growth of cassava. A $1{ }^{\circ} \mathrm{C}$ increase in HDD will lead to a decline of about $0.63 \mathrm{~kg} / \mathrm{ha}$ in cassava yield. In contrast to theoretical expectation, a negative relationship exists between VPD and cassava yield. This implies that soils moisture for the growth of cassava in Nigeria is inadequate. The fit of the model (adjusted R2 $=0.32$ ) implies that about one third of the changes in the yield of cassava across Nigerian states is explained by changes in weather variables. Overall, the model is significant as shown by the significance of the F statistic at $1 \%$ probability level.

\section{Cotton}

The regression results for cotton show a positive relationship between the yield of cotton and precipitation. A $10 \mathrm{~mm}$ increase in rainfall will lead to about $1.82 \mathrm{~kg} / \mathrm{hectare}$ increase in cotton yield. The marginal relationship with GDD is also positive. A $1{ }^{\circ} \mathrm{C}$ rise in GDD will bring about $0.22 \mathrm{~kg} /$ hectare increase in cotton yield. The relationship between cotton yield and HDD is strongly negative. A $1^{\circ} \mathrm{C}$ increase in HDD will cause up to 0.62 $\mathrm{kg} / \mathrm{hectare}$ decline in cotton yield. This suggests that high temperatures can have serious damaging effects on cotton yield. Vapor Pressure Deficit (VPD) is the most individually significant variable with a t statistic of $1 \%$. The fit of the model (adjusted R2 $=0.21$ ) implies that about $22 \%$ of the changes in the yield of cotton across Nigerian states is explained by changes in weather variables. Overall, the model is significant as shown by the significance of the $\mathrm{F}$ statistic at $1 \%$ probability level.

\section{Maize}

The summary of the regression results for maize is presented in Table 5 column 4 . The result shows weak but positive relationship between the yield of maize and average precipitation. The marginal relationship with GDD is also weakly positive but that with HDD is strongly negative. This suggests high temperatures can be damaging even when precipitation is not a constraint. A $1^{\circ} \mathrm{C}$ increase in HDD will cause a decline of about 0.2 $\mathrm{kg} /$ hectare in maize yield. Like cassava, the coefficient of VPD is negative and significant at $10 \%$ significant level. The fit of the model (adjusted R2 $=0.07$ ) indicates slight difference relative to the simple correlation with HDD.

\section{Sorghum}

The regression coefficients, standard errors and adjusted- $\mathrm{R}^{2}$ values for in respect of sorghum are reported in column 5 of Table 5. Like other crops, the result indicates positive and significant relationship between sorghum yield and precipitation. A $10 \mathrm{~mm}$ increase in daily rainfall will cause about $0.6 \mathrm{~kg} / \mathrm{hectare}$ increase in sorghum yield. Like cassava, the marginal relationship with both GDD and HDD is negative and statistically significant. As with other crops, high temperatures from $34^{\circ} \mathrm{C}$ have damaging effects on sorghum yield. The relationship of the yield with VPD is strongly negative and 


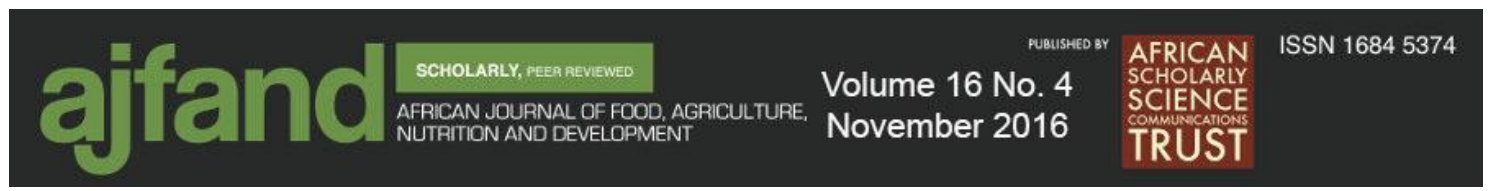

significant. An increase in soil moisture is desirable in order to stimulate increase in the yield of sorghum. The fit of model (adjusted R2 $=0.09$ ) indicates considerable improvement relative to the simple correlation with HDD.

\section{Rice}

The regression results for rice are reported in the last column of Table 5. The model shows strong and positive relationship with precipitation but no significant result is observed in the relationship of the yield with GDD. An increase in precipitation by $10 \mathrm{~mm}$ will lead to increase in the yield of rice by about $0.5 \mathrm{~kg} /$ hectare. The marginal relationship with HDD is also found to be negative, indicating a damaging effect on the yield. The fit of the model (adjusted R2 $=0.08$ ) also indicates considerable improvement relative to the simple correlation with HDD.

\section{DISCUSSION}

This paper examined the effects of extreme weather on five major staple crops in Nigeria that occupied prominent position in the nation's agricultural transformation agenda. In all cases, there are expected harmful impacts from extreme weather as shown by the strong and negative coefficient of HDD. For cassava and sorghum, an exposure to heat range that is expected to have positive effects on the yield is already showing negative influence. Given a clear evidence of increasing damage from extreme weather (HDD), the results are expected to have serious implication for crop productivity in the country. Possible adaptation measures to reduce the effects include development of irrigation and other infrastructure, flood control and improvement in crop varieties that are resistant to weather extremes. These measures are, however, costly and time consuming. An innovative way out of the problem is to incorporate weather index insurance in agriculture into the National Agricultural Insurance Scheme (NAIC). Although crop insurance exists in Nigeria, it covers less than $1 \%$ of the total population of farmers. This is often applied when financial institutions impose them as a condition for formal credit. In addition to the need for expanded coverage of more farmers by the nation's crop insurance, the results underscore the imperative reform of the national agricultural insurance scheme. It is high time the institution began thinking of a move towards a weather-based insurance scheme.

The overriding aim of Weather Index Insurance for Agriculture (WIIA) is to alleviate the negative impacts of extreme weather on farming households and village economies by compensating part of the damage caused to farming products. Such insurance products are already available in Japan, the U.S. and EU member countries. In the scheme, insurance claims are paid according to the number of days when temperature either falls below or exceeds certain agreed levels, in order to compensate the income loss caused by the cold or the extreme heat. An advantage of WIIA is that, actual damage to crops in individual farms need not be measured and verified. Instead, compensation is automatically paid out when a certain set of conditions are satisfied. Other advantages of index insurance include rapid payout and low transaction costs. However, in order to utilize WIIA the following points should be kept in mind: 


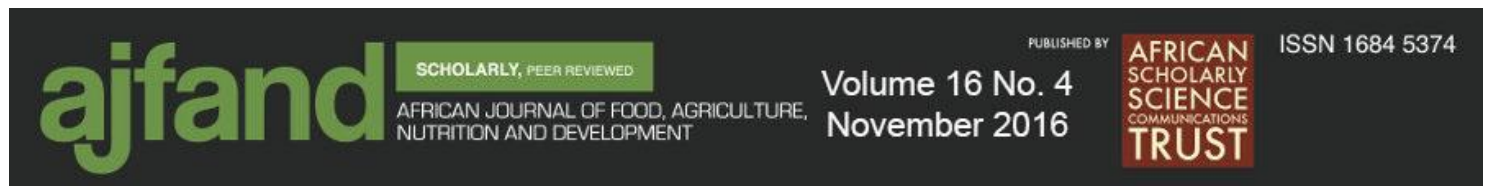

(1) Weather Index Insurance for Agriculture (WIIA) does not eliminate the risk of extreme weather conditions. Hence, considerable priority should still be placed on how to reduce greenhouse gas (GHG) emissions through mitigation measures.

(2) The Insurance does not eliminate the need for infrastructure development. It should be seen as a supplemental option. In this context, it should be considered as a short term approach to alleviate impact of extreme weather until infrastructure is fully developed and weather conditions return to their prior stable state.

\section{CONCLUSION}

In the study, a panel of Nigerian state-level crop yields were paired with a fine-scale weather data set that includes distribution of temperatures and precipitation, between the minimum and maximum across all days within the growing season for crops that are relevant to Nigerian Agricultural Transformation Agenda (ATA). Weather data obtained from National Meteorological Agency, are examined from January 1, 1991 to December 31, 2012. The results show that a high damage to cassava, cotton and maize is evident by the strong and negative coefficient of Harmful Degree Days (HDD). For sorghum and rice, an exposure to heat range that is expected to have positive effects on the yield is already showing negative influence. Given the above results, coupled with several problems associated with National Agricultural Insurance Corporation (NAIC) such as little access by farmers, high information asymmetric and transaction costs, crop insurance based on indices from Nigeria Meteorological Agency (NIMET) could fill the gap. This will adequately supplement existing adaptation measures such as development of irrigation and other infrastructure, flood control and improvement in crop varieties that are resistant to weather extremes.

\section{ACKNOWLEDGEMENTS}

This research work was funded by a grant from the Centre for Environmental Economics and Policy in Africa (CEEPA) (www.ceepa.co.za), financed by the Swedish Development Cooperation Agency (SIDA). I gratefully acknowledge the technical assistance and useful suggestions of resource persons and researchers that contributed to the improvement of this study at various CEEPA workshops. 


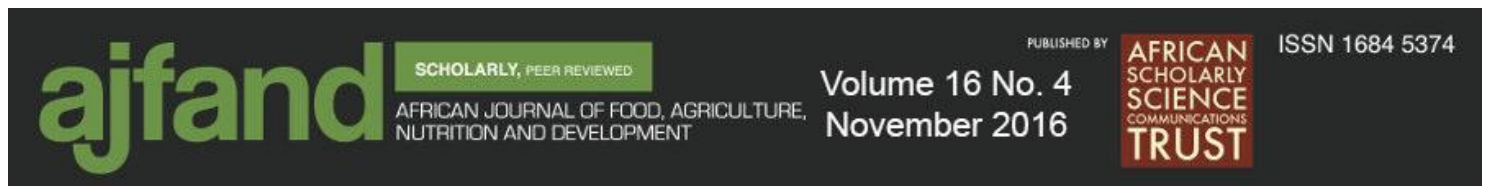

Table 1: Average recorded lowest and highest yields and average (kg/ha)

\begin{tabular}{|l|l|l|l|l|l|}
\hline Crop & $\begin{array}{l}\text { High yield } \\
(\mathrm{Kg} / \text { hectare })\end{array}$ & Year & $\begin{array}{l}\text { Low yield } \\
(\mathrm{Kg} / \text { hectare })\end{array}$ & Year & $\begin{array}{l}\text { Mean yield } \\
(\mathrm{Kg} / \text { hectare })\end{array}$ \\
\hline Cassava & 43.503 & 1999 & 1.085 & 2001 & 10.678 \\
\hline Rice & 17.083 & 2003 & 0.180 & 2001 & 1.861 \\
\hline Maize & 7.995 & 1991 & 0.141 & 2009 & 1.885 \\
\hline Sorghum & 4.111 & 2012 & 0.176 & 2012 & 1.242 \\
\hline Cotton & 5.454 & 1998 & 0.189 & 2012 & 1.649 \\
\hline
\end{tabular}

Source: Author's calculation

Table 2: Calendar for Selected Crops

\begin{tabular}{|l|l|l|l|l|l|}
\hline Agro-ecological zones & Crop & $\begin{array}{l}\text { Planting } \\
\text { period } \\
\text { onset }\end{array}$ & $\begin{array}{l}\text { Planting } \\
\text { Period end }\end{array}$ & Planting rate & $\begin{array}{l}\text { Cropping } \\
\text { cycle }\end{array}$ \\
\hline Derived savannah & Maize & $01 / 03$ & $31 / 08$ & $25-32$ & $100-120$ days \\
\hline Humid forest & Maize & $01 / 03$ & $31 / 08$ & $25-33$ & $100-120$ days \\
\hline $\begin{array}{l}\text { Northern Guinean } \\
\text { savannah }\end{array}$ & Maize & $01 / 03$ & $31 / 08$ & $25-30$ & $100-120$ days \\
\hline Derived savannah & Rice & $01 / 04$ & $31 / 05$ & 65 & $6-8$ months \\
\hline $\begin{array}{l}\text { Northern Guinean } \\
\text { savannah }\end{array}$ & Rice & $01 / 08$ & $31 / 07$ & 65 & $6-8$ months \\
\hline Humid forest & Rice & $01 / 04$ & $31 / 05$ & 65 & $6-8$ months \\
\hline $\begin{array}{l}\text { Southern Guinean } \\
\text { savannah }\end{array}$ & Rice & $01 / 04$ & $31 / 05$ & 65 & $6-8$ months \\
\hline $\begin{array}{l}\text { Southern Guinean } \\
\text { savannah }\end{array}$ & Sorghum & $01 / 08$ & $30 / 09$ & $7-10$ & $70-120$ days \\
\hline $\begin{array}{l}\text { Northern Guinean } \\
\text { savannah }\end{array}$ & Sorghum & $01 / 04$ & $30 / 06$ & $7-10$ & $70-120$ days \\
\hline Sudanese savannah & Sorghum & $01 / 04$ & $30 / 06$ & $7-10$ & $70-120$ days \\
\hline Derived savannah & Cassava & $01 / 03$ & $31 / 08$ & $6.913-1.3580$ & $18-24$ months \\
\hline Humid forest & Cassava & $01 / 03$ & $31 / 08$ & $6.913-1.3580$ & $18-24$ months \\
\hline $\begin{array}{l}\text { Northern Guinean } \\
\text { savannah }\end{array}$ & Cassava & $01 / 03$ & $31 / 08$ & $6.913-1.3580$ & $18-24$ months \\
\hline Sahelian savannah & Cassava & $01 / 07$ & $31 / 08$ & $6.913-1.3580$ & $18-24$ months \\
\hline $\begin{array}{l}\text { Southern Guinean } \\
\text { savannah }\end{array}$ & Cassava & $01 / 03$ & $31 / 08$ & $6.913-1.3580$ & $18-24$ months \\
\hline $\begin{array}{l}\text { Southern Guinean } \\
\text { savannah }\end{array}$ & Cotton & $15 / 06$ & $15 / 07$ & 15 & $150-180$ days \\
\hline $\begin{array}{l}\text { Northern Guinean } \\
\text { savannah }\end{array}$ & Cotton & $01 / 07$ & $15 / 07$ & 15 & $150-185$ days \\
Source & & & & & \\
\hline
\end{tabular}

Source: $[17,18]$ 


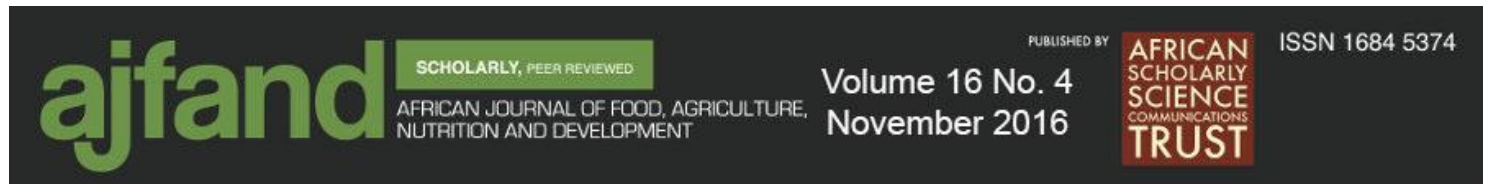

Table 3: Summary Statistics for Cumulative rainfall

\begin{tabular}{|l|l|l|l|l|l|}
\hline Crop & Minimum & Year & Maximum & Year & Mean \\
\hline Cassava & 366.2 & 1999 & 4243.1 & 2008 & 1495.1 \\
\hline Maize & 19.6 & 1992 & 2937.9 & 2009 & 1065.4 \\
\hline Cotton & 426.6 & 1992 & 1789.4 & 1995 & 939.4 \\
\hline Rice & 24.5 & 1992 & 2361 & 2004 & 469.7 \\
\hline Sorghum & 366.2 & 1991 & 1935.4 & 2007 & 896.5 \\
\hline
\end{tabular}

Source: Author's calculation 


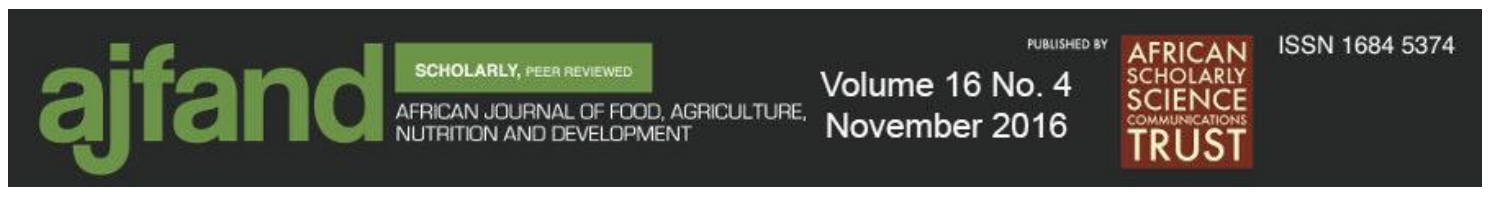

Table 4: Descriptive Statistics of Variables in the Regression Model

\begin{tabular}{|c|c|c|c|c|c|}
\hline Statistic & $\mathrm{N}$ & Mean & St. Dev. & Min & Max \\
\hline \multicolumn{6}{|c|}{ Cassava } \\
\hline Yield & 814 & 10.70 & 5.86 & 1.08 & 43.50 \\
\hline Rain & 814 & $1,435.78$ & 740.45 & 366.20 & $4,243.10$ \\
\hline GDD & 814 & $6,233.611$ & 748.19 & $2,424.50$ & $8,218.00$ \\
\hline HDD & 814 & 86.25 & 107.93 & 0.00 & 735.50 \\
\hline VPD & 814 & 2.40 & 0.60 & 1.44 & 4.81 \\
\hline \multicolumn{6}{|c|}{ Cotton } \\
\hline YIELD & 264 & 1.634 & 1.275 & 0.189 & 5.454 \\
\hline Rain & 264 & 823.597 & 232.141 & 377.700 & $1,562.500$ \\
\hline dday10c & 264 & $4,426.658$ & 629.823 & $2,424.500$ & $6,146.000$ \\
\hline dday34c & 264 & 60.202 & 78.164 & 0.000 & 548.024 \\
\hline Vpd & 264 & 2.651 & 0.505 & 1.616 & 4.828 \\
\hline \multicolumn{6}{|c|}{ Maize } \\
\hline YIELD & 814 & 1.853 & 1.101 & 0.141 & 7.955 \\
\hline Rain & 814 & $1,321.968$ & 655.244 & 194.200 & $3,490.900$ \\
\hline dday10C & 814 & $4,225.645$ & 620.088 & $1,411.500$ & $5,603.000$ \\
\hline dday34C & 814 & 63.363 & 84.949 & 0.000 & 497.986 \\
\hline $\mathrm{Vpd}$ & 814 & 2.213 & 0.628 & 1.219 & 5.296 \\
\hline \multicolumn{6}{|c|}{ Rice } \\
\hline Yield & 814 & 1.94 & 1.31 & 0.07 & 17.08 \\
\hline Rain & 814 & $1,345.372$ & 662.524 & 366.200 & $3,731.400$ \\
\hline GDD & 814 & $4,624.979$ & 597.469 & $2,002.000$ & $6,268.500$ \\
\hline HDD & 814 & 54.261 & 85.350 & 0.000 & 552.052 \\
\hline VPD & 814 & 2.202 & 0.619 & 1.312 & 4.802 \\
\hline \multicolumn{6}{|c|}{ Sorghum } \\
\hline YIELD & 462 & 1.225 & 0.513 & 0.176 & 4.111 \\
\hline Rain & 462 & 720.124 & 253.796 & 51.800 & $1,717.900$ \\
\hline dday10c & 462 & $2,763.360$ & 424.204 & 481.500 & $3,522.000$ \\
\hline dday34c & 462 & 71.445 & 68.658 & 0.000 & 310.509 \\
\hline $\mathrm{Vpd}$ & 462 & 2.068 & 0.606 & 1.197 & 4.078 \\
\hline
\end{tabular}

Source: Author's Calculation 


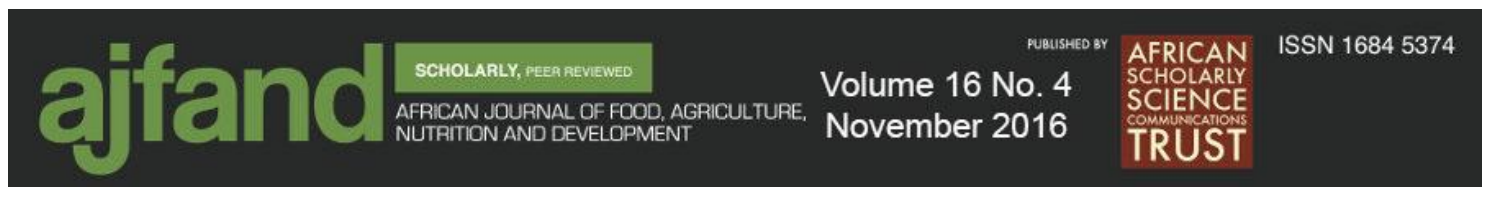

Table 5: The regression results for the relationship between crop yield and weather variables

\begin{tabular}{|l|l|l|l|l|l|}
\hline Variable & Cassava & Cotton & Maize & Sorghum & Rice \\
\hline Rain & -0.006 & $0.182^{*}$ & $0.026^{*}$ & $0.066^{*}$ & $0.05^{* *}$ \\
& $(0.37)$ & $(1.79)$ & $(1.77)$ & $(1.85)$ & $(2.25)$ \\
\hline Square rain & -0.000 & 0.000 & $-0.0001^{*}$ & -0.000 & -0.000 \\
& $(0.21)$ & $(1.42)$ & $(1.79)$ & $(-1.52)$ & $(-1,50)$ \\
\hline GDD & $-0.047^{*}$ & $0.218^{* *}$ & $0.008^{*}$ & $-0.016^{* *}$ & 0.062 \\
& $(-1.65)$ & $(2.35)$ & $(1.77)$ & $(-2.02)$ & $(0.071)$ \\
\hline HDD & $-0.628^{* * *}$ & $-0.616^{* *}$ & $-0.205^{* *}$ & $-0.219^{* *}$ & -0.332 \\
& $(-8.08)$ & $(-2.30)$ & $(-2.14)$ & $(-2.00)$ & $(-1.86)^{* *}$ \\
\hline Square & $0.0001^{* *}$ & $-0.00002^{*}$ & - & - & 0.000 \\
GDD & $(2.48)$ & $(-2.00)$ & & & $(0.48)$ \\
\hline Square & $0.001^{* * *}$ & 0.001 & $0.001^{* * *}$ & $0.001^{* *}$ & $0.001^{*}$ \\
HDD & $(8.19)$ & $(1.49)$ & $(2.80)$ & $(2.63)$ & $(2.10)$ \\
\hline VPD & $-30.907^{* * *}$ & $71.745^{* * *}$ & $-10.004^{* *}$ & $-8.263^{* *}$ & - \\
& $(-4.14)$ & $(4.25)$ & $(1.95)$ & $(2.38)$ & \\
\hline Constant & $362.208^{* * *}$ & $-525.210^{* * *}$ & 22.364 & 42.541 & $173.775^{* * *}$ \\
& $(5.22)$ & $(3.17)$ & $(1.12)$ & $(1.65)$ & $(11.03)$ \\
\hline $\mathrm{R}^{2}$ & 0.32 & 0.21 & 0.07 & 0.09 & 0.08 \\
\hline $\mathrm{F}$ & $55.11^{* * *}$ & $9.49^{* * *}$ & $10.81^{* * *}$ & $7.33^{* * *}$ & $15.17^{*}$ \\
\hline $\mathrm{N}$ & 814 & 264 & 814 & 462 & 814 \\
\hline
\end{tabular}

$*, * *, * * *$ indicate significant at $10 \%, 5 \%$ and $1 \%$ probability levels

Source: Author's calculation 


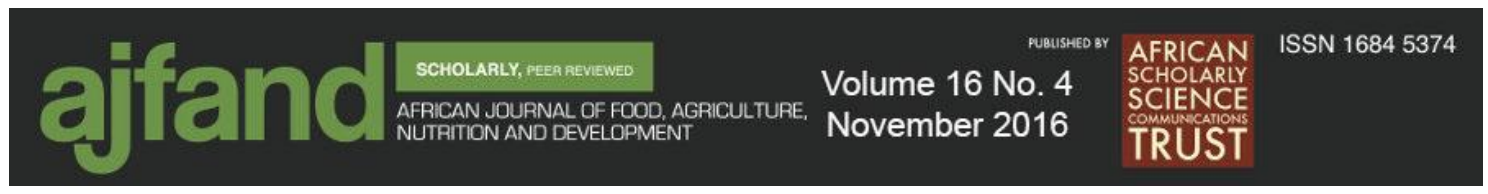

\section{REFERENCES}

1. Epstein PR and GP Chikwenhere Biodiversity questions. Science. 1994; 265: 510-511.

2. Rosenweig C and ML Parry Potential impact of climate change on wood food supply. Nature. 1994; 367: 133-138.

3. Deuschênes $\mathbf{O}$ and $\mathbf{M}$ Greenstone The Economic Impacts of Climate Change: Evidence from Agricultural Output and Random Fluctuations in Weather. The Ame. Econ. Rev. 2007; 97: 354-385.

4. Robertson SM A spatial model of agricultural land use with climate change for the Canadian Prairies. A PhD thesis, Department of Agricultural and Resource Economics University of Alberta 2012.

5. Chalise $\mathbf{L}$ and $\mathbf{R}$ Ghimire Effect of Climate Change on Pea nut's Yield in the State of Georgia, USA. Paper presented at the Southern Agriculture Economics Association (SAEA) annual meeting, Orlando, Florida. 2013.

6. Mendelsohn $\mathbf{R}$ The Impact of Climate Change on Agriculture in Developing Countries. J.l of Nat. Res. Policy Res., 2009; 1: 5-19.

7. Wang J, Mendelsohn R, Dinar A, Huang J, Rozelle S and L Zhang The impact of climate change on China's agriculture. Agric.l Econs. 2009; 40: 323 337.

8. Ajetomobi J, Ajiboye $\mathbf{A}$ and $\mathbf{H}$ Rashid Impacts of climate change on rice agriculture in Nigeria. Trop.l and Sub-trop.l Agro syst. 2011; 14: 613-622.

9. Rosenzweig C and M Parry Potential impact of climate change on world food supply In: Tietenberg T (Ed.) The Economics of Climate Change, Cheltenham, UK: Elgar 1997: 118-136.

10. Felkner J, Tazhibayeva $\mathbf{K}$ and $\mathbf{R}$ Townsend Impact of climate change on rice production in Thailand. Ame. Econ. Rev. 2009; 99: 205-210.

11. Soja AM and G Soja Effects of weather conditions on agricultural production in Austria between 1869 and 2003. Die Bodenkultur 2007; 58: 95-111.

12. Roberts JM, Schlenker W and J Eyer Agronomic Weather Measures in Econometric Models of Crop Yield with Implications for Climate Change. Ame. J. of Agric. Econs. 2012; 1093: 1-17.

13. Luo Q Temperature thresholds and crop production: A review. Climate Change 2011; 109: 583-598. 


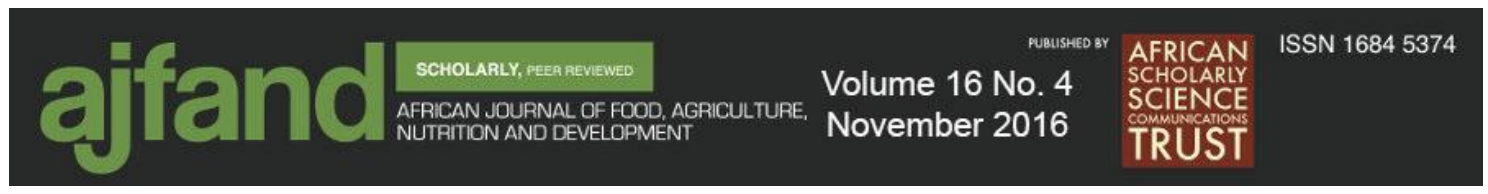

14. Le P Climate Change Impact on Crop Yield: Re-examined Evidence from Decreasing Diurnal Temperature Range. Paper Presented at the $18^{\text {th }}$ Annual Conference of the European Association of Environmental Economists, Rome, Italy 2011.

15. Sinclair TR and G Seligman Crop modeling from infancy to maturity. Agronomy Journal 1996; 88: 698-704.

16. Lobell DB, Celine B and PB Duffy Climate change uncertainty for daily minimum and maximum temperatures: A model comparison. Geo.l Res. Letters 2007; 34: 1-5.

17. USDA. Crop Calendar for Nigeria, http://fas.usda.gov/pecad/pecad.html (Accessed October 2015).

18. FAO. Crop Calendar www.fao.org/agriculture/seed/cropcalendar/cropcalendar.do (Accessed October 2015). 